\title{
Oral Localized Amyloidosis
}

\author{
Kenji Yamagata and Hiroki Bukawa \\ Oral and Maxillofacial Surgery, Clinical sciences, \\ Graduate School of Comprehensive Human Science, \\ University of Tsukuba \\ Japan
}

\section{Introduction}

Amyloidosis is characterized by the proteinaceous fibrillar material amyloid, which is formed by extracellular accumulations of the insoluble protein fibril. This rare disease results from a sequence of changes in protein folding (Sipe et al., 2010) and occurs in response to various cell dyscrasias or inflammatory conditions. Amyloid stained with hematoxylin and eosin appears as a homogeneous, eosinophilic amorphous substance; when stained with Congo red, it demonstrates green birefringence in polarized light. The amyloid deposits can be localized or systemic, and can be large enough to impair normal tissue function.

Localized amyloidosis is relatively mild in contrast to the large-organ involvement seen in the systemic disease. Localized amyloidosis has been described in almost every organ system. Some patients have a progressive form of amyloidosis that is difficult to manage and is associated with severe morbidity. However, how the systemic disease evolves remains unclear. In a survey of 35 patients with local amyloidosis, Paccalin et al. did not find any risk of developing a systemic disease from local amyloid deposits. They suggested that immunolabeling studies be routinely performed. Moreover, since the evolution of the local disease can be life-threatening, these authors recommended that patients be referred to specialists for further evaluation. Management requires close follow-up to exclude recurrence and to determine appropriate treatment of the symptoms (Paccalin et al., 2005).

Localized amyloidosis affecting the head and neck is uncommon and usually benign. The sites most commonly involved are the larynx, subglottis, and thyroid (Nandapalan et al., 1998; Pentenero et al., 2006). Amyloidosis of the oral cavity is less frequent, and usually appears as multiple soft nodules accompanied by yellow, red, blue, or purple coloring in the mucous membrane. Oral amyloidosis is quite uncommon and occurs mostly as localized amyloidosis (Pentenero et al., 2006; Pribitkin et al., 2003), although when present in the most frequent site, the tongue, it may be linked to the systemic disease. In this chapter we focus on the clinical features, diagnosis, management, and prognosis of amyloidosis arising in the oral cavity.

\section{Classification and types of amyloidosis}

The Nomenclature Committee of the International Society of Amyloidosis met in conjunction with the XII International Symposium on Amyloidosis in 2010 to recommend amyloid fibril protein nomenclature and to consider newly identified amyloid fibril proteins for inclusion in the nomenclature list (Sipe et al., 2010). Amyloidosis is classified as primary or secondary, 
based on the nature of the precursor plasma proteins that form the fibril deposits (Khan and Falk, 2001). The pathogenesis is multifactorial. Nonetheless, the final pathway, in which amyloid fibrils are formed in the extracellular matrix, is identical in all forms of the disease. All amyloid deposits have a common fibrillar structure, consisting of linear, aggregated fibrils with an approximate diameter of 7.5-10 $\mathrm{nm}$ and a cross $\beta$-pleated sheet conformation, as evidenced by x-ray diffraction (Steciuk et al., 2002).

Three major amyloid types have been defined. The amyloid light chain (AL) form is seen in primary and idiopathic amyloidosis when there is no associated disease, but it has also been associated with plasma cell dyscrasia and multiple myeloma. The immunoglobulin light chain variable region is the main component of AL deposits. These patients commonly produce urinary free monoclonal light chains of the $\mathrm{K}$ or $\lambda$ isotype, referred to as Bence Jones proteins. In a small percentage of AL amyloidosis cases, bone marrow plasma cells show clonal dominance of a light chain isotype. (Falk et al., 1997). Unlike multiple myeloma and monoclonal gammopathies, in which $\mathrm{K}$ chains are more frequent, in AL amyloidosis the ratio of $K$ to $\lambda$ light chains is 1:3 (Khan and Falk, 2001).

The amyloid A (AA) form of amyloidosis is seen in patients with secondary, acquired, or reactive amyloidosis, and is associated with chronic disease. AA deposits consist of fragments of at least 5 different molecular forms (Kluve-Beckerman et al., 1988) and are commonly seen in patients with rheumatoid arthritis or inflammatory bowel disease (Husby, 1985). The acute phase protein formed is serum amyloid A, which is produced under the regulation of cytokines that include tumor necrosis factor $\alpha 3$. The amino acid sequence in the AA protein is highly conserved, in contrast to the high variability of the amino acid sequence in the AL protein (Skinner, 1992).

Another type of secondary amyloidosis may occur in patients undergoing dialysis. In these patients, $\beta 2$ microglobulin, which is part of the Class I major histocompatibility complex antigen, fails to cross the dialysis membrane, resulting in amyloid fibril formation (Danesh and Ho, 2001). These fibrils may be deposited in joints, (resulting in arthritis), periarticular tissue (resulting in carpal tunnel syndrome), and in bones (resulting in cysts) (Khan and Falk, 2001). The third major type of amyloidosis is familial transthyretin-associated amyloidosis (ATTR) (Stoor et al., 2004). ATTR derives from a group of autosomal-dominant diseases in which, beginning in midlife, a mutant protein forms amyloid fibrils. In this case, the aberrant protein is transthyretin, a thyroxine transport protein that is capable of binding retinol. Other hereditary forms of amyloidosis involve mutations in other serum proteins such as apolipoprotein A1, fibrinogen, and gelsolin (Khan and Falk, 2001).

Oral localized amyloidosis has not been associated with either multiple myeloma or systemic amyloidosis, and does not usually progress to a systemic disease. In 13 cases of reported oral localized amyloidosis, 4 were AL, 2 were AA, and no type was described for the remaining 7 (Table 1). None of these cases appeared to have systemic involvement. However, when amyloidosis of the oral mucosa is diagnosed, further investigation is mandatory, both to evaluate the function of the organs most frequently involved in systemic amyloidosis, such as the liver, kidney, and heart, and to exclude an underlying plasma cell dyscrasia.

\section{Clinical features and diagnosis of oral localized amyloidosis}

\subsection{Epidemiology}

Although amyloidosis is rare, with an incidence of 12 cases per million population per year, this figure is no less than the incidence of several more widely recognized conditions, 
including chronic myeloid leukemia and Guillain-Barré syndrome. While the incidence of familial amyloidosis is unknown, it represents $10 \%$ to $20 \%$ of AL amyloidosis cases seen in referral centers (Falk et al., 1997).

Oral involvement, while identical in all forms of amyloidosis, has been reported in $40 \%$ of patients with AL amyloidosis (Mardinger et al., 1999; Reinish et al., 1994) but appears to be less frequent in patients with AA amyloidosis (Mardinger et al., 1999). Oral localized amyloidosis is quite uncommon (Pentenero et al., 2006; Pribitkin et al., 2003). To our knowledge, only 13 cases of oral localized amyloidosis have been reported (Table 1).

\begin{tabular}{|c|c|c|c|c|c|c|c|}
\hline $\begin{array}{c}\text { Case } \\
\text { No }\end{array}$ & Authors & Age & Sex & Location & Symptom & Type & Treatment \\
\hline 1 & Takeda et al (1987) & 58 & M & Floor of mouth & ND & ND & ND \\
\hline 2 & Haraguchi et al (1997) & 62 & F & Tongue & $\begin{array}{c}\text { Tongue } \\
\text { discomfort }\end{array}$ & AA & Surgery \\
\hline 3 & Koren et al (1998) & 33 & M & Tongue & Tongue pain & ND & ND \\
\hline 4 & Alvi et al (1999) & 65 & M & Soft palate & Bleeding & ND & None \\
\hline 5 & Asaumi et al (2001) & 84 & F & $\begin{array}{c}\text { Tongue, lower lip, } \\
\text { buccal mucosa }\end{array}$ & Swelling & ND & ND \\
\hline 6 & Stoor et al (2004) & 80 & M & Hard palate & None & AL & Surgery \\
\hline 7 & Pentenero et al (2006) & 68 & F & Hard palate & None & AA & None \\
\hline 8 & Balatsouras et al (2007) & 45 & F & Soft palate & Fullness of & ND & None \\
\hline 9 & Henly et al (2007) & 63 & F & Hard palate & Palatal sore & AL & None \\
\hline 10 & Aono et al (2008) & 74 & F & Hard palate & Painless nodule & AL & None \\
\hline 11 & Angiero et al (2010) & 36 & M & Tongue & None & ND & ND \\
\hline 12 & Angiero et al (2010) & 63 & F & Tongue & Swelling & ND & ND \\
\hline 13 & Angiero et al (2010) & 57 & M & Tongue & Macroglossia & AL & ND \\
\hline
\end{tabular}

ND: not described

Table 1. Reported cases of localized amyloidosis arising in the oral cavity

\subsection{Clinical features and symptoms}

In systemic amyloidosis, systemic AL amyloidosis has the widest spectrum of tissue and organ involvement. The most frequent initial symptoms are fatigue and weight loss, but the diagnosis is usually not made until signs and symptoms are linked to a particular organ (Falk et al., 1997). The kidney and heart are the organs most commonly involved, either alone or in combination. Renal amyloidosis may manifest as proteinuria, which may be clinically evident as mild renal dysfunction. Normal serum creatinine and blood urea nitrogen concentrations may mask massive proteinuria, which may be accompanied by profound edema and hypoalbuminemia (Stoopler et al., 2003). Cardiac complications of 
amyloidosis are most likely to manifest as rapid-onset and progressive congestive heart failure. Electrocardiographic results may be normal, or may demonstrate a pattern of myocardiac infarction in the absence of coronary artery disease (Falk et al., 1997). Echocardiography may reveal a thickened ventricle and an ejection fraction in the low normal or mildly reduced range (Falk et al., 1987). Autonomic and sensory neuropathy are relatively common (Falk et al., 1997). Hepatomegaly is commonly seen in patients with AL amyloidosis, but splenomegaly is rare. Macroglossia, which is characterized by enlargement and stiffening of the tongue, is a frequent finding. If muscle weakness is present, amyloid deposits may be present elsewhere, resulting in the "shoulder-pad sign," nail dystrophy, or, in rare cases, alopecia (Falk et al., 1997).

The characteristic features of oral localized amyloidosis usually resemble those of benign tumors (Muto et al., 1991; Pentenero et al., 2006). The location in the oral cavity seems to have diagnostic importance, as amyloidosis of the tongue has been suggested as a clinical sign associated with blood dyscrasia or a dialysis-related lesion, while none of the reported cases affecting the palate seem to have systemic involvement (Alvi and Goldstein, 1999; Balatsouras et al., 2007; Pentenero et al., 2006; Pribitkin et al., 2003; Stoor et al., 2004). Oral amyloidosis usually appears as multiple soft nodules accompanied by yellow, red, blue, purple, or mixed colors in the mucous membrane (Pentenero et al., 2006, Aono et al., 2009). The symptoms reported in known cases of oral localized amyloidosis include bleeding, painless nodules, palatal sores, swelling, and macroglossia (Table 1). Differentiating amyloidosis from a tumor is clinically difficult and requires a biopsy of the lesion.

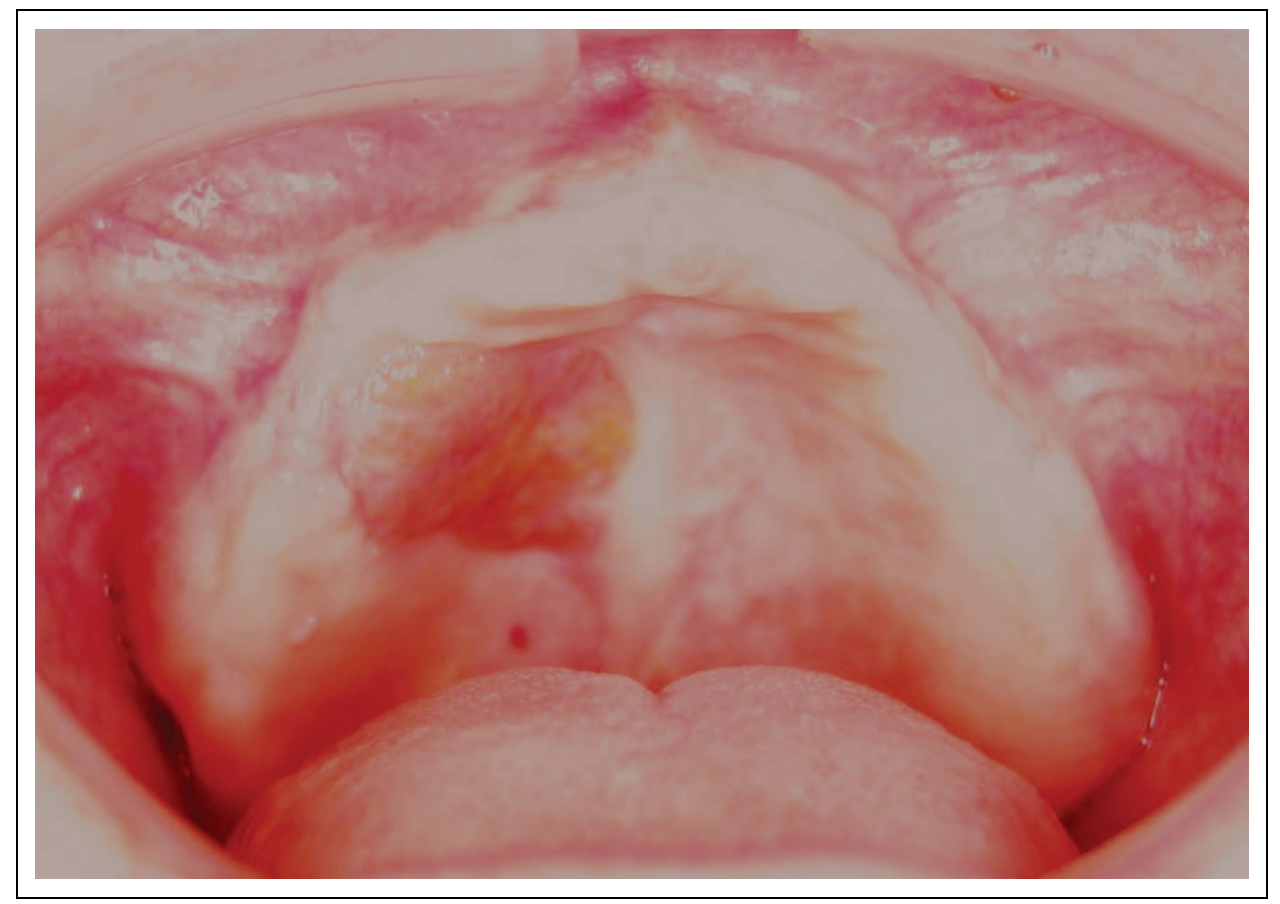

Fig. 1. Examination of the oral cavity. Oral cavity showing a yellow and red papilliform mass on the right side of the palate. The mass was painless and elastic to the touch 


\subsection{Diagnosis and pathological features}

To establish a diagnosis of amyloidosis, clinical suspicions require histological confirmation. Although affected organs such as kidneys are often biopsied, more risky procedures can be avoided by simple subcutaneous aspiration of abdominal fat using a wide-bore needle and syringe (Duston et al., 1987; Libbey et al., 1983). This has an advantage over other widely used methods, such as rectal biopsy, in that it is less invasive but at least as effective. Most oral amyloidosis cases are easily biopsied with local anesthesia.

A tissue biopsy is used to establish a definitive diagnosis. When examined by light microscopy, amyloid stained with hematoxylin and eosin appears as a homogeneous eosinophilic, amorphous substance. When stained with Congo red and observed under polarized light, it shows an apple-green birefringence (Gertz et al., 2005). If the tissue sample yields a positive result, the type of amyloidosis must next be determined (Figure 2).

Since AL is the most common type of amyloidosis, serum or urine immunofixation electrophoresis is used to search for a clonal disorder. If the result is negative, immunohistochemical staining of a bone marrow specimen should be performed to search for $\mathrm{K}$ or $\lambda$ light chains. The specific type of amyloid fibril can also be identified by light or electron microscopy with labeled antibodies using immunogold staining; this has been useful for identifying mixed forms of amyloidosis. In the absence of plasma cell dyscrasia, a variant transthyretin should be sought by isoelectric focusing of the serum, which will separate variant from wild-type transthyretin (Khan and Falk, 2001). Genetic testing should be performed if a variant transthyretin is found, since the specific mutation affects prognosis and management. AA amyloidosis is suspected in patients with a chronic inflammatory condition when AL and ATTR amyloidosis have been excluded. The diagnosis is confirmed by immunohistochemical staining for the AA protein.

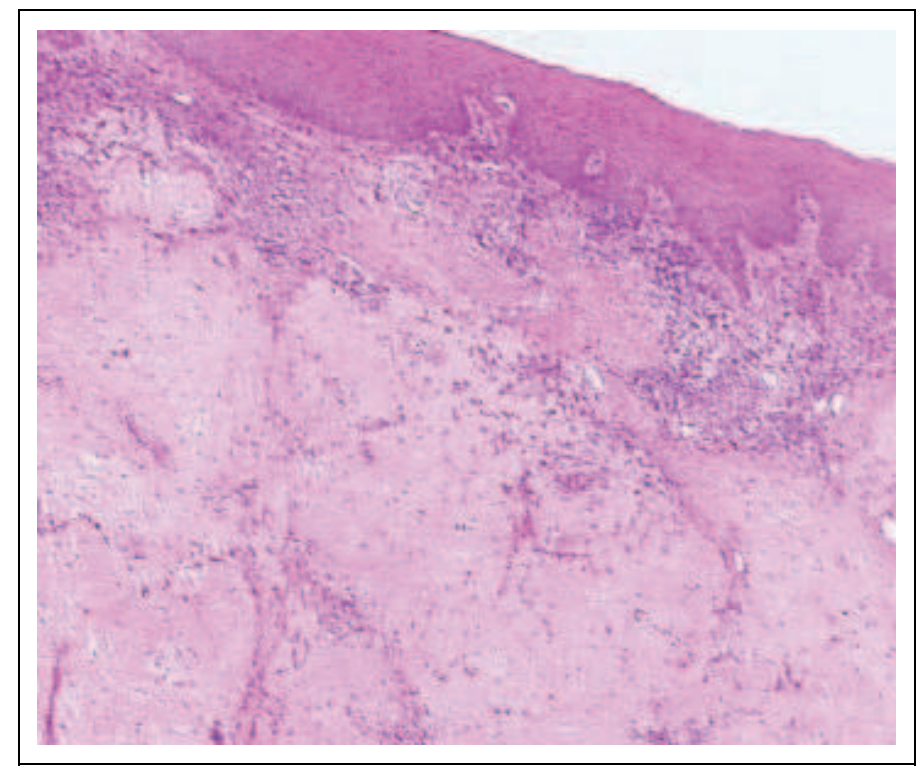

(a) 


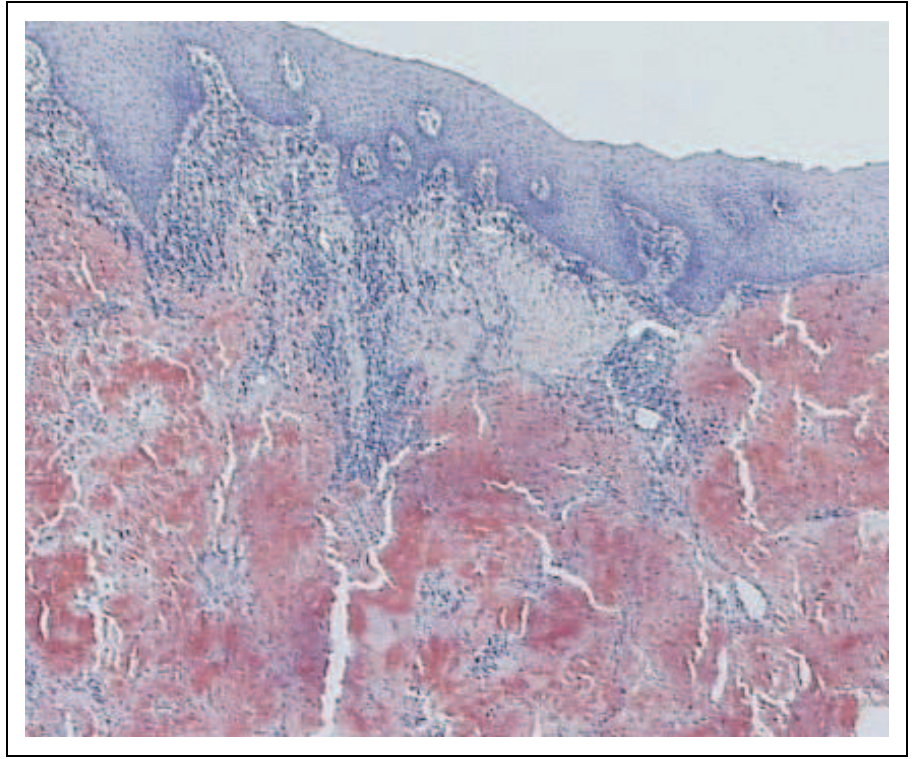

(b)

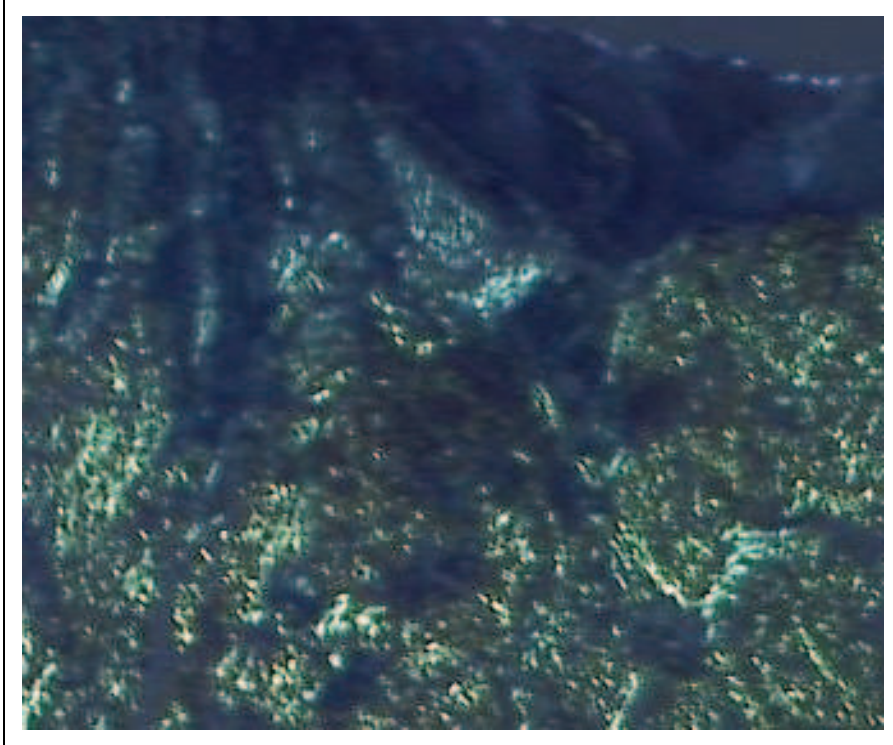

(c)

Fig. 2. (a) Hematoxylin and eosin staining showing an eosinophilic amorphous material in the connective tissue beneath the intact epithelium. (b) Congo red staining showing a red homogenous material under light microscopy. (c) The same area showing apple green birefringence under polarized light. $(\mathrm{a}-\mathrm{c})$ Magnification: original $\times 100$ 
Noninvasive diagnostic tests include ${ }^{123}$ I serum amyloid P scintigraphy to locate systemic amyloid deposits (Burke et al., 1990) and Tc-99m phosphate radionuclide imaging to demonstrate amyloid deposits in the skin and muscle, including the tongue (Hawkins et al., 1990). In one report, CT scans of amyloid tissue showed soft-tissue masses with no significant enhancement or only slight enhancement (Asaumi et al., 2001). It has also been reported that CT scanning can discriminate between localized and diffuse disease in patients with amyloidosis of the respiratory tract (Gillmore and Hawkins, 1999; Shah et al., 2002). Amyloidosis signals on MR images closely resemble those of skeletal muscle. Moreover, dynamic MR images may be helpful in evaluating localized amyloidosis, because it reveals characteristic features of such lesions (Asaumi et al., 2001). MR images have been shown to be useful in evaluating deposits before and after excision attempts, and could prevent the need for further endoscopic examination (Chin et al., 2004; Ichioka et al., 2004).

\section{Typical localized oral amyloidosis}

\subsection{Tongue amyloidosis}

The tongue is the most frequent site of oral amyloidosis. It may be diffusely enlarged due to macroglossia or nodular deposits, or it may be clinically unaffected (Salisbury and Jacoway, 1983; van der Wal et al., 1984). When deposits are extensive, macroglossia may develop; the tongue loses its elasticity and may be firm, dry, hard, fissured, ulcerated, hemorrhagic, and occasionally red and painful. The tongue becomes stiff, interfering with speech, chewing, and swallowing. Surgical management may be required if airway obstruction is anticipated (Mardinger et al., 1999).

Macroglossia is less common in AA than in AL amyloidosis (Mardinger et al., 1999). It is difficult to correlate a particular tongue lesion with a type of amyloid deposit. As lesions frequently recur, requiring repeated excisions, surgical intervention should be considered only in extreme cases of macroglossia with possible airway obstruction (Mardinger et al., 1999; Reinish et al., 1994). Clinicians note that tongue biopsy must include muscle tissue to be of diagnostic value. A biopsy of the tongue is recommended if the presence of amyloidosis is suspected, whether or not the patient is experiencing symptoms. However, other researchers have noted that tongue biopsy is diagnostic in only $60 \%$ of cases (Nandapalan et al., 1998). Deep incisional biopsies increase the risk of damaging the tongue's neurovascular supply, and can be painful. This area may also be prone to delayed healing and scarring due to mechanical irritation of the biopsy site (Stoopler et al., 2003). Although most tongue amyloidosis is secondary, five cases of localized tongue amyloidosis have been reported (Angiero et al., 2010; Haraguchi et al., 1997; Koren et al., 1998). One case was determined to be AL amyloidosis, another was AA, and the amyloidosis type was not described in the remaining cases. Reported symptoms included tongue swelling, macroglossia, and tongue pain (Table 1).

\subsection{Palatal amyloidosis}

Localized amyloidosis of the palate is extremely rare; only six cases have been reported (Alvi and Goldstein, 1999; Balatsouras et al., 2007; Gertz et al., 2005; Muto et al., 1991). Oral localized amyloidosis has not been generally associated with either multiple myeloma or systemic amyloidosis (Alvi and Goldstein, 1999; Balatsouras et al., 2007; Pentenero et al., 2006; Pribitkin et al., 2003; Stoor et al., 2004), and does not usually progress to systemic disease (Stoor et al., 2004). None of the reported cases affecting the palate appeared to have 
systemic involvement. Of the six patients with localized amyloidosis of the palate, three were diagnosed with AL amyloidosis and one with AA; the type was not reported for the other two patients. While some patients did not experience symptoms, others noted painless nodules, bleeding, and other symptoms. Five patients were not treated for the amyloidosis, and one was treated with surgery (Table 1).

Amyloid deposits have been found in other areas of the oral cavity and maxillofacial complex; however, not all of these areas can be biopsied. Localized amyloidosis has been reported in the nasal septum and maxillary sinus, and an unusual case involving the parotid gland was documented (Nandapalan et al., 1998). These sites are difficult to biopsy because of the mechanical complexities involved. Delgado and Mosqueda (Delgado and Mosqueda, 1989) found amyloidosis in the labial minor salivary glands, which are possible to biopsy (Stoopler et al., 2003).

\section{Managing oral localized amyloidosis}

In systemic amyloidosis, treatment is directed both toward the affected organ and the specific amyloidosis type. Nephritic involvement may necessitate diuretics and dialysis. Cardiac involvement may also require diuretics. Calcium channel blockers may exacerbate amyloid heart disease (Gertz et al., 1985) and should also be avoided because of their negative isotropism (Khan and Falk, 2001). Digoxin is contraindicated in cardiac amyloidosis, because it binds to amyloid fibrils and may be toxic at therapeutic levels (Khan and Falk, 2001). Previously reported therapies include conventional melphalan and predonisone therapy, dexamethasone-based regimens, thalidomide, stem cell transplantation, and investigational therapies (Gertz et al., 2005). The prognosis for patients with AL amyloidosis depends on the extent of organ involvement. Generally, a patient's prognosis is poor if the condition is left untreated, with a median survival of 1 to 2 years (Kyle and Gertz, 1995).

An optimal therapeutic strategy for amyloidosis would be designed to dissolve amyloid deposits or to prevent their accumulation. Patients with localized amyloidosis generally do not require systemic therapy, and management can be supportive or localized. Surgical intervention may be required when airway obstruction is a concern (Mardinger et al., 1999). Excision can be considered, but lesions often persist or recur (Paccalin et al., 2005). Thalidomide has been shown to be effective in treating refractory multiple myeloma, and is now being considered for treating AL amyloidosis (Singhal et al., 1999). Etarnacept, a tumor necrosis factor receptor antagonist, has shown some early success in treating symptoms of cardiac amyloidosis (Khan and Falk, 2001). The definitive therapy for ATTR amyloidosis is liver transplantation, because of the organ's transthyretin production.

For localized forms of amyloidosis, adjuvant therapies such as chemotherapy and steroids have not been shown to be beneficial. Surgical intervention is usual, but laser treatment may be used if surgical intervention is problematic. Alternatively, the patient may simply be kept under observation (Pentenero et al., 2006; Viggor et al., 2009). While management of oral localized amyloidosis is not commonly needed, local surgical or laser excision can improve functional impairment (Pentenero et al., 2006). Only two of the 13 known cases of oral localized amyloidosis were treated with surgery (Table 1 ).

\section{Prognosis of oral localized amyloidosis}

The prognosis of amyloidosis depends on the specific type and the organs involved. If AL amyloidosis is left untreated, the prognosis of a patient with cardiac involvement is poor, 
with a median survival of 1 to 2 years (Kyle and Gertz, 1995). Patients with ATTR amyloidosis may survive up to 15 years after diagnosis, but survival varies with the specific mutation and the time of diagnosis - the younger the age of presentation, the worse the outcome. The prognosis of patients with AA amyloidosis is affected by the underlying condition.

The prognosis of patients with oral localized amyloidosis is uncertain because of the rarity of the disease. Careful follow-up is advised to monitor its progression. Although rare cases of progressive amyloidosis have been reported (Bartels et al., 2004), there is no documentation to suggest that localized amyloidosis can progress to a systemic involvement (Nandapalan et al., 1998). Although local surgical or laser excision can be used to eliminate functional impairment, recurrences have been observed (Pentenero et al., 2006). The low risk of further generalized disease does not mean that localized amyloidosis is benign; it can be clinically silent or have significant consequences.

\section{Conclusion}

Oral localized amyloidosis is uncommon and has characteristics resembling those of benign tumors. It usually appears as multiple soft nodules accompanied by yellow, red, blue, or purple coloring in the mucous membrane. Differentiating amyloidosis from a tumor is clinically difficult and requires a biopsy of the lesion. Amyloidosis management is not commonly needed, but local surgical or laser excision can be useful for eliminating functional impairment even though the lesions may recur. The prognosis for patients with localized amyloidosis is uncertain because of the rarity of the disease, and careful follow-up is advised to monitor its progression.

\section{References}

Alvi A, and Goldstein MN. (1999). Amyloidosis of the palate. Otolaryngol Head Neck Surg, Vol. 120, No. 2, (February 1999), pp. 287, ISSN 0194-5998

Angiero F, Seramondi R, Magistro S, Crippa R, Benedicenti S, Rizzardi C, and Cattoretti G. (2010). Amyloid deposition in the tongue: clinical and histopathological profile. Anticancer Res, Vol. 30, No. 7, (August 2010), pp. 3009-3014, ISSN 1791-7530

Aono J, Yamagata K, and Yoshida H. (2009). Local amyloidosis in the hard palate: a case report. Oral Maxillofac Surg, Vol. 13, No. 2, (May 2009), pp. 119-122, ISSN 1865-1550

Asaumi J, Yanagi Y, Hisatomi M, Konouchi H, and Kishi K. (2001). CT and MR imaging of localized amyloidosis. Eur J Radiol, Vol. 39, No. 2, (August 2001), pp. 83-87, ISSN 0720-048X

Balatsouras DG, Eliopoulos P, Assimakopoulos D, and Korres S. (2007). Primary local amyloidosis of the palate. Otolaryngol Head Neck Surg, Vol. 137, No. 2, (August 2007), pp. 348-349, ISSN 0194-5998

Bartels H, Dikkers FG, van der Wal JE, Lokhorst HM, and Hazenberg BP. (2004). Laryngeal amyloidosis: localized versus systemic disease and update on diagnosis and therapy. Ann Otol Rhinol Laryngol, Vol. 113, No. 9, (September 2004), pp. 741-748, 0003-4894

Burke TS, Tatum JL, and Fratkin MJ. (1990). Accumulation of Tc-99m MDP in amyloidosis involving the tongue. Clin Nucl Med, Vol. 15, No. 2, (February 1990), pp. 107-109, ISSN 0363-9762 
Chin SC, Fatterpeckar G, Kao CH, Chen CY, and Som PM. (2004). Amyloidosis concurrently involving the sinonasal cavities and larynx. AJNR Am J Neuroradiol, Vol. 25, No. 4, (April 2004), pp. 636-638, ISSN 0195-6108

Danesh F, and Ho LT. (2001). Dialysis-related amyloidosis: history and clinical manifestations. Semin Dial, Vol. 14, No. 2, (March 2001), pp. 80-85, ISSN 0894-0959

Delgado WA, and Mosqueda A. (1989). A highly sensitive method for diagnosis of secondary amyloidosis by labial salivary gland biopsy. J Oral Pathol Med, Vol. 18, No. 5, (May 1989), pp. 310-314, ISSN 0904-2512

Duston MA, Skinner M, Shirahama T, and Cohen AS. (1987). Diagnosis of amyloidosis by abdominal fat aspiration. Analysis of four years' experience. Am J Med, Vol. 82, No. 3, (March 1987), pp. 412-414, ISSN 0002-9343

Falk RH, Comenzo RL, and Skinner M. (1997). The systemic amyloidoses. N Engl J Med, Vol. 337, No. 13, (September 1997), pp. 898-909, ISSN 0028-4793

Falk RH, Plehn JF, Deering T, Schick EC, Jr., Boinay P, Rubinow A, Skinner M, and Cohen AS. (1987). Sensitivity and specificity of the echocardiographic features of cardiac amyloidosis. Am J Cardiol, Vol. 59, No. 5, (February 1987), pp. 418-422, ISSN 00029149

Gejyo F, Yamada T, Odani S, Nakagawa Y, Arakawa M, Kunitomo T, Kataoka H, Suzuki M, Hirasawa Y, Shirahama T, and et al. (1985). A new form of amyloid protein associated with chronic hemodialysis was identified as beta 2-microglobulin. Biochem Biophys Res Commun, Vol. 129, No. 3, (June 1985), pp. 701-706, ISSN 0006291X

Gertz MA, Falk RH, Skinner M, Cohen AS, and Kyle RA. (1985). Worsening of congestive heart failure in amyloid heart disease treated by calcium channel-blocking agents. Am J Cardiol, Vol. 55, No. 13, (June 1985), pp. 1645, ISSN 0002-9149

Gertz MA, Lacy MQ, Dispenzieri A, and Hayman SR. (2005). Amyloidosis: diagnosis and management. Clin Lymphoma Myeloma, Vol. 6, No. 3, (December 2005), pp. 208-219, ISSN 1557-9190

Gillmore JD, and Hawkins PN. (1999). Amyloidosis and the respiratory tract. Thorax, Vol. 54, No. 5, (April 1999), pp. 444-451, ISSN 0040-6376

Haraguchi H, Ohashi K, Yamada M, Hasegawa M, Maeda S, and Komatsuzaki A. (1997). Primary localized nodular tongue amyloidosis associated with Sjogren's syndrome. ORL J Otorhinolaryngol Relat Spec, Vol. 59, No. 1, (January 1997), pp. 60-63, ISSN 0301-1569

Hawkins PN, Lavender JP, and Pepys MB. (1990). Evaluation of systemic amyloidosis by scintigraphy with 123I-labeled serum amyloid P component. N Engl J Med, Vol. 323, No. 8, (August 1990), pp. 508-513, ISSN 0028-4793

Husby G. (1985). Amyloidosis and rheumatoid arthritis. Clin Exp Rheumatol, Vol. 3, No. 2, (April 1985), pp. 173-180, ISSN 0392-856X

Ichioka K, Utsunomiya N, Ueda N, Matsui Y, Yoshimura K, and Terai A. (2004). Primary localized amyloidosis of urethra: magnetic resonance imaging findings. Urology, Vol. 64, No. 2, (August 2004), pp. 376-378, ISSN 1527-9995

Khan MF, and Falk RH. (2001). Amyloidosis. Postgrad Med J, Vol. 77, No. 913, (October 2001), pp. 686-693, ISSN 0032-5473

Kluve-Beckerman B, Dwulet FE, and Benson MD. (1988). Human serum amyloid A. Three hepatic mRNAs and the corresponding proteins in one person. J Clin Invest, Vol. 82, No. 5, (November 1988), pp. 1670-1675, ISSN 0021-9738 
Koren R, Veltman V, Halpern M, Szabo R, and Gal R. (1998). Localized amyloid tumor of the tongue. A case report and review of the literature. Rom J Morphol Embryol, Vol. 44, No. 1-4, (February 2005), pp. 179-182, ISSN 1220-0522

Kyle RA, and Gertz MA. (1995). Primary systemic amyloidosis: clinical and laboratory features in 474 cases. Semin Hematol, Vol. 32, No. 1, (January 1995), pp. 45-59, ISSN 0037-1963

Libbey CA, Skinner M, and Cohen AS. (1983). Use of abdominal fat tissue aspirate in the diagnosis of systemic amyloidosis. Arch Intern Med, Vol. 143, No. 8, (August 1983), pp. 1549-1552, ISSN 0003-9926

Mardinger O, Rotenberg L, Chaushu G, and Taicher S. (1999). Surgical management of macroglossia due to primary amyloidosis. Int J Oral Maxillofac Surg, Vol. 28, No. 2, (April 1999), pp. 129-131, ISSN 0901-5027

Muto T, Sato K, and Lutcavage GJ. (1991). Multiple nodules of the lip, cheeks, and tongue. J Oral Maxillofac Surg, Vol. 49, No. 9, (September 1991), pp. 1003-1006, ISSN 02782391

Nandapalan V, Jones TM, Morar P, Clark AH, and Jones AS. (1998). Localized amyloidosis of the parotid gland: a case report and review of the localized amyloidosis of the head and neck. Head Neck, Vol. 20, No. 1, (February 1998), pp. 73-78, ISSN 1043-3074

Paccalin M, Hachulla E, Cazalet C, Tricot L, Carreiro M, Rubi M, Grateau G, and Roblot P. (2005). Localized amyloidosis: a survey of 35 French cases. Amyloid, Vol. 12, No. 4, (January 2006), pp. 239-245, ISSN 1350-6129

Pentenero M, Davico Bonino L, Tomasini C, Conrotto D, and Gandolfo S. (2006). Localized oral amyloidosis of the palate. Amyloid, Vol. 13, No. 1, (May 2006), pp. 42-46, ISSN 1350-6129

Pribitkin E, Friedman O, O'Hara B, Cunnane MF, Levi D, Rosen M, Keane WM, and Sataloff RT. (2003). Amyloidosis of the upper aerodigestive tract. Laryngoscope, Vol. 113, No. 12, (December 2003), pp. 2095-2101, ISSN 0023-852X

Reinish EI, Raviv M, Srolovitz H, and Gornitsky M. (1994). Tongue, primary amyloidosis, and multiple myeloma. Oral Surg Oral Med Oral Pathol, Vol. 77, No. 2, (February 1994), pp. 121-125, ISSN 0030-4220

Salisbury PL, 3rd, and Jacoway JR. (1983). Oral amyloidosis: a late complication of multiple myeloma. Oral Surg Oral Med Oral Pathol, Vol. 56, No. 1, (July 1983), pp. 48-50, ISSN 0030-4220

Shah PL, Gillmore JD, Copley SJ, Collins JV, Wells AU, du Bois RM, Hawkins PN, and Nicholson AG. (2002). The importance of complete screening for amyloid fibril type and systemic disease in patients with amyloidosis in the respiratory tract. Sarcoidosis Vasc Diffuse Lung Dis, Vol. 19, No. 2, (July 2002), pp. 134-142, ISSN 11240490

Singhal S, Mehta J, Desikan R, Ayers D, Roberson P, Eddlemon P, Munshi N, Anaissie E, Wilson C, Dhodapkar M, Zeddis J, and Barlogie B. (1999). Antitumor activity of thalidomide in refractory multiple myeloma. N Engl J Med, Vol. 341, No. 21, (November 1999), pp. 1565-1571, ISSN 0028-4793

Sipe JD, Benson MD, Buxbaum JN, Ikeda S, Merlini G, Saraiva MJ, and Westermark P. (2010). Amyloid fibril protein nomenclature: 2010 recommendations from the nomenclature committee of the International Society of Amyloidosis. Amyloid, Vol. 17, No. 3-4, (November 2010), pp. 101-104, ISSN 1744-2818 
Skinner M. (1992). Protein AA/SAA. J Intern Med, Vol. 232, No. 6, (December 1992), pp. 513514, ISSN 0954-6820

Steciuk A, Dompmartin A, Troussard X, Verneuil L, Macro M, Comoz F, and Leroy D. (2002). Cutaneous amyloidosis and possible association with systemic amyloidosis. Int J Dermatol, Vol. 41, No. 3, (May 2002), pp. 127-132, ISSN 0011-9059

Stoopler ET, Sollecito TP, and Chen SY. (2003). Amyloid deposition in the oral cavity: a retrospective study and review of the literature. Oral Surg Oral Med Oral Pathol Oral Radiol Endod, Vol. 95, No. 6, (June 2003), pp. 674-680, ISSN 1079-2104

Stoor P, Suuronen R, Lindqvist C, Hietanen J, and Laine P. (2004). Local primary (AL) amyloidosis in the palate. A case report. Int J Oral Maxillofac Surg, Vol. 33, No. 4, (May 2004), pp. 402-403, ISSN 0901-5027

van der Wal N, Henzen-Logmans S, van der Kwast WA, and van der Waal I. (1984). Amyloidosis of the tongue: a clinical and postmortem study. J Oral Pathol, Vol. 13, No. 6, (December 1984), pp. 632-639, ISSN 0300-9777

Viggor SF, Frezzini C, Farthing PM, Freeman CO, Yeoman CM, and Thornhill MH. (2009). Amyloidosis: an unusual case of persistent oral ulceration. Oral Surg Oral Med Oral Pathol Oral Radiol Endod, Vol. 108, No. 5, (September 2009), pp. e46-50, ISSN 1528395X 


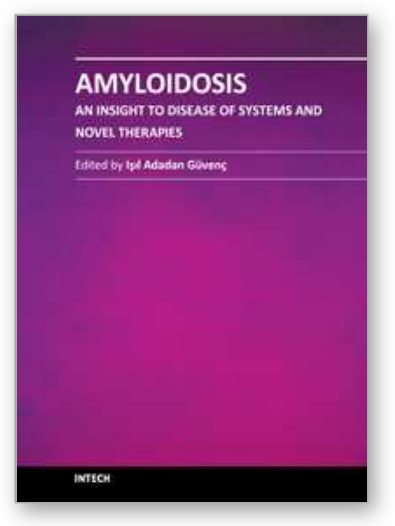

\author{
Amyloidosis - An Insight to Disease of Systems and Novel \\ Therapies \\ Edited by Dr. Işıl Adadan Güvenç
}

ISBN 978-953-307-795-6

Hard cover, 194 pages

Publisher InTech

Published online 16, November, 2011

Published in print edition November, 2011

Amyloidosis is a benign, slowly progressive condition characterized by the presence of extracellular fibrillar proteins in various organs and tissues. It has systemic or localized forms. Both systemic and localized amyloidosis have been a point of interest for many researchers and there have been a growing number of case reports in the literature for the last decade. The aim of this book is to help the reader become familiar with the presentation, diagnosis and treatment modalities of systemic and localized amyloidosis of specific organs or systems and also cover the latest advancements in therapy.

\title{
How to reference
}

In order to correctly reference this scholarly work, feel free to copy and paste the following:

Kenji Yamagata and Hiroki Bukawa (2011). Oral Localized Amyloidosis, Amyloidosis - An Insight to Disease of Systems and Novel Therapies, Dr. Işıl Adadan Güvenç (Ed.), ISBN: 978-953-307-795-6, InTech, Available from: http://www.intechopen.com/books/amyloidosis-an-insight-to-disease-of-systems-and-noveltherapies/oral-localized-amyloidosis

\section{INTECH}

open science | open minds

\section{InTech Europe}

University Campus STeP Ri

Slavka Krautzeka 83/A

51000 Rijeka, Croatia

Phone: +385 (51) 770447

Fax: +385 (51) 686166

www.intechopen.com

\section{InTech China}

Unit 405, Office Block, Hotel Equatorial Shanghai

No.65, Yan An Road (West), Shanghai, 200040, China

中国上海市延安西路65号上海国际贵都大饭店办公楼 405 单元

Phone: +86-21-62489820

Fax: +86-21-62489821 
(C) 2011 The Author(s). Licensee IntechOpen. This is an open access article distributed under the terms of the Creative Commons Attribution 3.0 License, which permits unrestricted use, distribution, and reproduction in any medium, provided the original work is properly cited. 